\title{
Halal Conception and Other Factors Affecting Income Distribution in Islam
}

\author{
Sahraman Hadji Latif ${ }^{*}$
}

Received: 20.03 .2019

Accepted: 02.11.2019

DOI: $10.25272 /$ ijisef.542534

Type: Research Article

\begin{abstract}
This paper examines and analyses the vital role of halal conception and its impact in mitigating and reducing the problem of unjust income distribution in our society. It also further expounds some relevant approaches to different economic systems in addressing income inequality. Generally, the conception of halal earning is not only associated with consumptions and devotional acts. Halal, in general, is a term that encompasses all aspects of lawful and unlawful in Islam including economic activities. For Muslims, halal earning is not only mandated by the Almighty God, but it is also indispensable for the acceptance of their religious acts. In relation to its significance in society, halal conception has indisputable impacts on the socio-economic problems of our society. Undeniably, one of the challenging economic issues in our society is the continuous rising of income inequality where the rich become richer and the poor become poorer. This unjust income distribution not only widens the undesirable gap between rich and poor people but also empirically brings socio-economic predicaments in our society. However, the conception of halal earnings is of remarkable mechanism can response the issue of unjust income distribution. Halal earnings can allocate economic resources efficiently and reduce income inequality in our society. The rising concentration of wealth in the hands of few rich individuals has something to do with high returns from proliferation of unlawful professions and economic activities in our society.
\end{abstract}

Keywords: Halal Conception, Income Distribution, Earnings

Jel Code: N30, P46, Z12

\footnotetext{
* Mindanao State University-Marawi City, Philippines, maranaopeace@gmail.com, ORCID: https://orcid.org/0000-0002-4212-4218
} 


\section{Introduction}

One of the complex issues in economic development today is the continuous increase in income disparity in developing and developed countries. The unfair distribution of income and wealth among people our society entails socio-economic impacts in our society. Rich people are becoming richer and low-income people are getting poorer without concrete solutions from conventional economic systems. Governments and Non-Government Organizations (NGOs) have proposed various policy measures such tax regulations and government transfer payments to the poor to resolve the problem of income gap between affluent and low-income people. Unfortunately, those policies measured are not enough to address the said issue. The latest report by Oxfam's International (2017) emphasized how rich people in the world own and enjoy world economic resources while the rest of the unprivileged low-income people are suffering from poverty. The report showed that eight men own the same wealth as the 3.6 billion people that are composed of poorest half of humanity. This alarming scenario of unjust income distribution poses challenging solutions. However, as complete of life, Islam provides achievable and viable solutions for all problems of humankind and provides guidance and rules for each angle of human actions and conducts. Any activity or conduct of a Muslim, which is within the framework of Shari'ah rules and principles, is lawful and anything that is against those principles and rules is impermissible. Unlawful and lawful in Islam are known "haram" and "halal" respectively. Islam encourages everyone to uphold permissible thing or manner and provides rules and guidance to nonpermissible professions, trading and economic activities that will lead to acquiring wealth unlawfully, and support income inequality in the society (Ayub, 2007). For instance, earning for living is indispensable and necessary for all living human beings for survival. However, Income and wealth earned from unlawful ways and activities such as interest, gambling, corruption, and other immoral economic activities are totally prohibited (al-Qaradawi,1997) Hence, this paper analyses the comparative approaches of three economic systems, conventional, socialism and Islam in addressing income inequality. Specifically, it discusses the vital role of halal earnings conceptions and their impact on mitigating and reducing the problem of unjust income distribution in our society.

\section{Concept of Halal in Islam}

The word "halal" is derived from the Arabic word "halla" which means to be lawful, legal, and permissible and its opposite is "haram" which means prohibited. It is sometimes also referred to like food that is lawful to eat but generally, halal does not only confine to consumption of foods rather it has a wide scope of applications in all economic and non-economic activities. Halal refers to everything that is permissible in Islamic law such as acceptable behaviour, speech, dress, manner, and food (Al-Jallad, 2008, p. 79). There are five categories of rulings in Islamic law for every humankind action. These are fard (obligatory), mandub (recommended), Mubah (permissible), Makruh (detestable), and haram (unlawful).According to Kamali (2013), the term "halal" is more frequently mentioned in the Qur' an and Hadith while its synonymous term like Mubāh or Jāiz is always used in figh literature. It refers to an "act, object or conduct 
over which the individual has freedom of choice and its exercise does not carry either a reward or a punishment" (p. 2). Conversely, Al-Qaradawi (2001) defines "haram" as "that which the Law-Giver has absolutely prohibited; anyone who commits it is liable to incur to the punishment of Allah in the hereafter as well the legal punishment in this world". Moreover, doubtful is "Mashbooh" which means uncertain or doubtful. It is between halal and haram and should be avoided because it might fall into haram when there is no clear evidence that confirms its lawfulness.

There are two classifications of haram as Imam Ghazali (1993) provided. Firstly, anything which is naturally unlawful. Secondly, earnings which are unlawful (p. 62). However, some Muslim scholars stressed that haram can be categorized into three classifications. First, unlawful by its own sake or the thing itself is inherently forbidden (haram lidhatihi) such as murder, theft, and what Allah mentioned in the Qur'an like dead meat, blood, the flesh of pig, and that animal which has been dedicated to other than Allah, the strangled animal, animal struck to death, animal killed by a fall, animal killed by being bitten by the horn, animals which wild beasts have eaten, and animals sacrificed on stones set up for altars/idols (Qur'an 5:3). Second, unlawful due to external factors (Haram Ligairihi) such as sales with riba. Selling is permitted but riba is totally prohibited. Third, Unlawfulness caused by invalidity and impoliteness of its underlying contract (Karim, 2005 p. 28). Furthermore, Kamali (2013) divided halal (mubah) into three subdivisions. First, mubah, a state that does not give harm to the individual whether it is done or not like travelling, hunting and walking. Second, halal due to necessity and its commission becomes permissible.

\section{A. Underpinnings and Implications of Halal Earnings}

There are foundations of halal earnings that should be put in mind and observed by Muslims while looking to have lawful earnings (Darussalam, 2013). Firstly, Muslims should believe that only Allah that provides provision for us. The sole provider of sustenance of all livings is the Almighty Allah. Allah says in the Qur'an, (20:132), “We ask not of you a provision. We provide sustenance to you ". He also said, "And kill not your children for fear of poverty. We provided for them and for you (Qur'an, 17: 31). Secondly, it is our duty to strive hard to look for halal earnings. Allah says in the Qur'an, (62:10) "So when the prayer is finished, spread out through the earth and seek Allah's wealth, and remember Allah a lot so that you may be successful". Thirdly, it is mandated to seek provision (earnings) in a prescribed Shari'ah. Abu Hurairah reported that Allah's messenger said" "O people, Allah is Good and He, therefore, accepts only that which is good" (Sahih Muslim: 1015). Lastly, we should spend our wealth in an Islamic prescribed way of spending. Allah says in the Qur'an, 17:26-27) "But spend not extravagantly (your wealth) in the manner of a spendthrift. Verily, spendthrifts are brethren of the shayatien (devils), and the shaytan (Devil Satan) is ever ungrateful to his lord.

Halal earning is very important for Muslims because it does not only indispensable to support the material necessities of life rather than it also very relevant to devotional acts (ibadat).It is not just the prohibition of consumption of wine, pork, blood or dead animal but it also covers 
business transactions and manners. There are some vital implications and significances of Halal earnings on Muslims: First, it is Divine Prescription. The halal injunction is a divine prescription where only the Almighty Allah has the authority to determine it. Since it is God's direction, halal has its own inherent and distinct significance and value. Halal is a part of Islamic legal and moral system of Islam derived from the Qur' an and Sunnah. Allah said "He commands them what is right and forbids them what is wrong, he makes lawful the things that are wholesome and makes unlawful the things that are bad and lifts from them their burdens and the yokes that were upon them."(Qur'an, 7:157). Second, halal earning is mandatory for Muslims. Looking for halal earnings is mandatory for every capable Muslim. Abdullah Ibn Masud narrated that Allah's Messenger once remarked: “It is obligatory to seek to earn Halal after other obligatory observations i.e. prayers etc." (Sunan Al-Baihaqi, 6:126).Third, Halal is prerequisite for the acceptance of prayer and Ibadah. The acceptance of the worship of Muslims depends on the consumption of halal earnings. Muslim earnings and spending have an effect on all types of religious activities. A true Muslim should follow what Allah mandates and avoid what Allah prohibits. There are preconditions for the acceptance of Ibadat and one of those conditions is consumption of halal things. It is reported that the Holy Prophet (peace be upon him) and he gave an example about the case of a person who came to a holy place in a state that his hair was messy, and his body covered with dust from his upper to bottom. He made himself busy in his supplications and said, "O my God, O my Lord!" Nevertheless, his food and drink are harams. His outfits are haram and he was brought up with a haram wealth. So, how could his prayers be accepted?" (Muslim, 1686). Fourth, Halal is blissful and signifies health. Barakah means blessing in Islam and eating of lawful earnings has a blessing. There are some who earned lot of income from unlawful sources but no blessing from Allah for their income. Some people earn little income through halal ways and sources, but this income becomes sufficient for him and his family due to the Baraka with it. It is recorded in a long Hadith that the Messenger of Allah (saws) said: "The person, who earns unlawfully and then spends for his needs; he will be deprived of blessings. If he gives something in charity, his act will not be accepted. When he leaves his wealth as inheritance, then it will lead him to Hell." (Musnad Ahmad, 36:72). Fifth, seeking halal Income leads us to paradise. A person will not move from his place until he is asked where he got his income. Tirmidhi narrated that the Prophet Muhammad said: The two feet of the son of Adam will not move from near his Lord on the Day of Judgement until he is asked about five questions: about his life; How he expended it; about his youth, how he took care of it; about his affluence, how he earned it; and where he spent it and about that which he acted upon from the knowledge he acquired.

\section{Concept and Issues of Income Distribution}

Income distribution is one of the key concerns in economic development. It has been observed that income disparity has been alarming in some countries particularly in low-income countries. Rich few people have controlled the majority of economic resources and low-income people could not able to catch up the affluent people. Rich people become richer and poor 
people are getting poorer and the gap between few rich people and majority low-income people is quite escalating. Developed and developing countries have integrated into their economic policies on how this issue be addressed. The Dictionary of Economics defines Income distribution as "the way in which income is distributed between various individuals or firms who receive it "(p.97). Income distribution can be analyzed into two main ways: These are functional distribution of income and size distribution of income. The first one refers to the distribution of income among factors of production and the latter is the distribution of income among persons (Cowell, 2007, p. 2). When this distribution of income is disproportionately distributed among people than income inequality exists. Income inequality is defined as "the disproportionate distribution of total national income among households" (Todaro\&Smith, 2015). Generally, there are three basic sources of households' income. The income of households maybe derived from wages or salaries received in exchange for labor, from property like capital and land, from government (Case, Fair \& Oster, 2012, p. 367). However, the households' incomes are not proportionately distributed among society due to some relevant factors. Some acquire and enjoy higher income and luxurious lives and the rest are suffering from poverty and hunger due to income imbalances in its distribution. In developing and developed countries, Income distribution has been an issue and observed as one of the causes of increasing poverty. The correlation between income inequality and poverty is undeniable. Todaro and Smith (2015), argued that the presence of inequality among the poor is indispensable for the analysis of the severity of poverty and the impact of market changes on the poverty level. In fact, the concern for income inequality is more priority than poverty because high level of income inequality will lead to economic inefficiency and inefficient allocation of assets and lower economic growth. With high-income inequality, the rate of savings in the economy will be decreased because the higher marginal rate of savings is found in middle-income people. Moreover, high inequality weakens social stability and unity. The political power of the affluent people is strengthened and will to lead to economic bargaining power and rent-seeking behaviors including bribery, lobbying, cronyism, and nepotism. Social disorders like corruption, crimes, and demonstrations will gradually increase as result of the income disparity. Additionally, extreme inequality is seen as unfair and unjust particularly when income disparity is caused by luck or inappropriate ways (p. 231-232).

\section{Factors Affecting Income Distribution}

Economists have been debating on the factors that drive income distribution among people. The reasons why income distribution is not equal among different sectors of society are due to some relevant factors. People have different incomes due to differences in their natural abilities and talents. It can also be related to their efforts to learn and acquire knowledge that help them to earn more. Lastly, some people are economically lagged behind due to lack of preparedness to work hard and be productive (El-Ashker\&Wilson 2006, p. 74). According to Kaasa (2003) in her study, there are five main groups of the causes of disparity in the distribution of income. These are economic growth and development, macroeconomics, demographic, political, and natural or cultural factors (p.29). One of the popular theories 
pertaining to income inequality and the relationship between economic growth and income inequality is Kuznets's Hypothesis or sometimes known as Inverted U Relationship. According to this theory, as incomes or Gross Domestic Product increases, income inequality also increases, but it will gradually decrease. However, this can be explained when the economy is getting better, wealthy people have various opportunities to increase their wealth and movement of labor force from agriculture to industrial sector. Certainly, technological breakthrough contributes also to income distribution. Technology creates new markets and brings variety of opportunities. However, some people have been lagged behind as technology advances, labor competition increases due to increasing demand for high skilled workers over low skilled workers. Moreover, government has huge expenditures for society through transfers, subsidies, grants and other social programs that can contribute to fair distribution of income and wealth. The higher the share of government sector in economy, the lower the income inequality. Democratization and liberation including globalization are undeniable among the factors of income distribution. Land concentration, corruption, cultural variation and shadow economy also trigger income inequality (Kaasa, 2003).

\section{A. Income Distribution in Capitalism, Socialism and Islam}

According to the capitalist economy, wealth produced from cooperation of the factors of production can be distributed over the four factors of production, capital in the shape of interest, labor in the shape of wage, and land in the form of rent, and entrepreneurship in the form of profit that brings together the other factors (Shafi, 1976). However, according to this system, this distribution should be left to the market as being self-regulating and having special characteristics that provide incentives to market participants. Factor prices determine the factor distribution of income among labor, land, and capital. By this, the concept of fair distribution of income in capitalism can be understood through the concept of the marginal product of factor and the Marginal Productivity Theory of Income distribution. The theory proposed by Neo-classical economists emphasizes that all factors of production end up receiving rewards determined by their productivity as measured by marginal revue products. Households earn income from the payment for the factors of production they supply in input markets. However, the income of workers, landlords, and capital owners depends on the market wage rates, price of capital, and rental value respectively (Krugman, W. \&Wells, R, 2005); Case, K., Fair, R. \& Oster, S. (2012). Hence, in competitive market, the equilibrium price of each input is equal to its marginal revenue. For instance, market wage is equal to the equilibrium value of the marginal product of labor. The same case applies to other factors of production. Therefore, when the factor's price is equal to value of its marginal productivity, then the distribution is fair and ethical with the assumption that the prices are determined through demand and supply forces. Conversely, income distribution in communism or socialism is quite different from that of capitalism. In contrast to capitalism, Carl Marx argued that the capitalists exploit workers, and this made the milestone of his call for workers revolution. So, the theory of income distribution in this economic system can be described as theory of exploitation. The value of the products made by worker is higher than the actual 
price of labor he received in capitalism. Hence, the difference goes to capitalists as profit and this is what Marx called surplus value. From this theory of surplus-value, Carl Marx says that core of capitalism is exploitation (Kahf, 2014, p. 224). In Socialism, the resources are owned by the state including factors of production, capital, and land. Therefore, the issue of interest and rent does not arise at all under this system. Labor is the most important factor relating to income distribution. Only Labor is considered to have a right to wealth, which gets share in the form of wages (Shafi, 1976, p. 14).

In Islam, the differences in income and wealth of people have been recognized in the Qur'an. Hence, Islam does not aim to attain perfect distribution of income. Fair distribution of income in Islam does not mean that all members of society should have equal income. Islam gives more important consideration for fair distribution of income through halal activities and any type of income from impermissible means is unacceptable in Islam. Moreover, just distribution of income must be consistent with Islamic principles and with human efforts described by competitive market. In other words, just distribution of income in Islam can be achieved when income earnings are derived only from economic activities prescribed by Islam as permissible (Abdelrahman, 2013, p. 161). According to Kahf (2014), Islam approaches to income distribution is comprehensive, detailed and realistic. Comprehensively, income distribution in Islam begins from the early point of distribution and realistically, it considers actual market, and market forces. However, Islam recognizes the limitedness of the market and does not ignore the role of the government. Moreover, it deals with every aspect of income distribution through detailed approach. Mufti Muhammad Shafi (1976) emphasized that at least there are three objectives of income distribution in Islam. Establishment of ideal and practical economic system, for others to get rightfully what is due to them and to reduce the concentration of wealth to certain few people.

There are two ways for an individual to procure and possess rights to property. First, property can be acquired through creative and fruitful efforts and labor. Second, it can be through exchanges, contracts, donations, and inheritance from others. Furthermore, there are obligations to be observed with respect to property rights as prescribed by Shari'ah. Just income distribution can be achieved when the use of property and sharing of its processes must be observed and there is an obligation to take care of the property from destruction, wastage, squandering, and misuse of the property for unlawful purposes (Iqbal \&Mirakhor, 2011, p. 33). Moreover, Islam recognizes the importance of market economy to allocate resources efficiently and effectively as promoted by capitalism through perfect competition. However, when factors of the production market are not perfectly competitive market, this can be one factor of unfair income distribution in Islam. The market in Islam should be perfect competition. In Islam, the factors of production are capital, land, and labor, risk-taking managerial executive labor (Kahf, 2014). However, it is not interest but profit is the reward of capital. According to Mufti Shafi ( 1976), "while admitting to a certain extent the principle of supply and demand, Islam has at the same time laid down certain injunctions for both the 
employer and the employee, so that the system of supply and demand has come to be based on human sympathy and brotherhood, and not on self-interest" (p. 29).

Personal income distribution is the most important challenge when it comes to income distribution. It is because this is redistribution for those people who have not participated in the process of production, but they are in need of help and support. Islam does not promote laziness and jobless in society but it recognizes the rights of some groups of people that have a right to wealth as prescribed by Allah. Their rights towards wealth are through the principle of "invariant claim ownership" which upholds that all human beings have a right to the resources provided by Allah to mankind (Iqbal\&Mirakhor, 2011). Hence, the unfair personal distribution of income and wealth is due to the concentration of wealth to some certain people who are stingy and not willing to give the rights of the low-income people to their income and wealth according to the prescriptions given by Islamic rules and principles. Hence, to achieve fair income and wealth distribution, mandatory and voluntary approaches are needed to redeem some faction of income and wealth from the rich people to be given to low-income people. Islam imposes zakah for rich Muslims whose income and wealth reach the nisab or the minimum amount of assets that subject to zakah. Another approach in Islam is through Islamic inheritance law. After the death of Muslims, the estate of a person shall be distributed to his/her legal heirs and relatives in an equitable and just manner prescribed by the Qur'an and Sunnah. Furthermore, Fai and Anfal (Ghanimah) distribution also are one of the Islamic approaches to promote equitable income distribution. Fai' was the spoils of war that were acquired without exertion of actual battle and this will go to the entire population, while Anfal is the spoils of war that gained from the enemy through actual fighting. Moreover, tax or zakah known as jizyah is imposed on non-Muslim living in the vicinity of Muslim territories (ElAshker\&Wilson, 2006, p. 84).Islam encourages Muslims to do benevolent charities and donations out of their excess wealth for the benefits of needy people and society. Through these benevolent deeds, Muslims will be rewarded for their sincere support for others who in some way in need of financial support. This recommended acts in Islam to promote social solidarity, brotherhood and cooperation and much more for fair distribution of income in the society. Through sadaqah, the rights of less privileged people in the society are redeemed voluntarily from the income and wealth of the affluent people.

\section{Just Income Distribution through Halal Earnings and Economic Activities}

Islamic Economic system as a rule-based system defines principles, rules, and institutions for the society to comply in order to achieve practical and realistic development. In Our societies, there are some people in the society who earned higher income and accumulated huge amounts of wealth due to unethical trading, professions and economic activities that provide them with lucrative profits. Income and wealth play vital roles in society and economy, and its utilization is encouraged to provide benefits and improve the well-being of the society. However, accumulation of wealth should be through lawful earnings from good, productive and beneficial work prescribed by Islamic Law because wealth is only a means for the achievement of ultimate human objectives, not an end itself (Askari, Iqbal\&Mirakhor, 2015, 
66). According to Abdelrahman (2013), fair distribution of income in Islam does not mean attainment of equality of income among individuals. It means first that the income should be from halal activities “(p.161). When Islam came as a religion with its complete and comprehensive legal system including social and ethical injunctions for the interests of humanity, it provides guidance pertaining to prohibited and lawful things as part of its total Shari'ah legal system. It aims to remove harmful and serve to provide ease for day-to-day transactions and designed to benefit everyone in society regardless of its socio-economic status (Luetge, 2013, p, 884). Islam provides guidelines for looking for earnings through lawful means and prescribes professions, trading and economic activities that are lawful in Shari' ah and any earning gained from lawful ways are encouraged and any earnings gained from haram ways are considered prohibited. Nowadays, rich people become richer due to professions, trading and economic activities, which deem immoral and brings about injustices to the society. According to the report of Oxfam's International entitled "An Economy for the $99 \%$ ", the reason for global higher income inequality is unjustifiable strategy of large corporations in reducing the cost of inputs of productions including the wages and salaries of the workers while keeping high profits for themselves. In other, workers are not compensated justly and equitably based on their productivity. There is also forced labor in some countries, where workers are paid below minimum wage. Moreover, the report added that another reason why income is not distributed properly is the avoidance of tax by big companies, which leads to a great loss on the part of the government to provide good services to its society. Furthermore, elite people in society monopolize the shares of big and lucrative businesses and do rent-seeking behavior through crony capitalism and lobbying in order to control the market at the expense of the common good.

Anent to this, Islam also has preventive measures to mitigate or reduce the concentration of wealth at hands of few people through the concept of halal activities and earnings. Looking for halal earnings for Muslims is mandatory and halal earnings always associated with the acceptance of worship. As a rule in Islam, Islam prohibits all trading, professions and economic activities that entail injustices and harm to others. Among others is prohibition of interest, hoarding, monopoly, and monopolistic practices, gambling, corruption and bribery, robbery, stealing and other malpractices that lead inefficiency in the allocation of resources. Islam encourages Muslims to be generous and helpful instead of wasting resources or wealth. By this, Israf (extravagance) which is spending more than necessity, and tabzir (wastage) is spending especially on objects or things that are prohibited by Allah are obviously unlawful.

Hence, Islam unconditionally prohibits interest (riba) because of its undeniably negative impacts on the society and economy as whole. Instead, Islam promotes and endorses the risksharing principle as an instrument for fair distribution of income and wealth. In interest-based contracts, the entire risk is transferred to borrower, creditor is always entitled to returns and principal, and this undoubtedly brings the continuous accumulation of wealth on the part of creditors. Abdelrahman (2013), explained clearly how interest system maintains a pattern of income distribution and favorably benefits the wealthy and large business ventures and 
deprives small medium enterprises. Interest-based financial institutions provide easily credit facilities to large companies due to creditworthiness while the small-medium enterprises that serve as agents of growth are rarely given an opportunity to avail credit facilities provided by interest-based financial institutions due to various requirements and hence, they are discriminated and charged with higher interest rate (p. 129). However, in Risk- sharing financing, where risks and outcomes of the ventures are shared among the participants will empower the participation of the low-income people in economic activities and promotes solidarity, brotherhood, productivity and good behavior such as trust and honesty. Since the risks and profits are shared, this can lead to proper and fair distribution of income. Interestingly, income earned from interest is considered by famous author Andrew Sayer (2016) as unearned income in his book entitled “Why we can't afford the Rich "because it is produced without hard effort and work". According to him, Wealth from lending money with interest is charged is fundamentally unearned, because the rich are simply taking advantage of an unequal power relationship between themselves and the less well off.

Furthermore, monopolistic practices, corruptions, and gambling businesses also make the rich richer. Perfectly competitive competition and market forces are undoubtedly important for their roles to achieve economic efficiency. However, these must operate within the boundaries of clean mechanism of moral values and the principle of accountability before God, justice and human brotherhood (Chapra, 1992, p. 220-221). A monopoly is unlawful because it prevents entry of other sellers/producers and sets higher prices beyond the normal and competitive prices by reducing production. Hence, resources are not allocated efficiency when monopoly prevails in the market and consumer's wellbeing is affected. Consumers are forced to buy the goods with abnormal prices, and monopolists are better off through higher profits earned while consumers are worse off. In developing countries, some people acquired income through corruption. Government officials use their power in the government to earn income out of government funds. A research conducted by Gupta (1998) showed that corruption can influence positively the income inequality and poverty by decreasing economic growth, progressivity of tax system, the level, and effectiveness of social expenditure, the development of human capital and access to education. Besides, there are rich people who have enriched themselves through profits out of unlawful professions and ventures at the expense of others such as businesses deal with pork, wine, prostitution, gambling, and illegal drugs. It is unimaginable that due to the increasing growth of unlawful profitable ventures, income inequality also increases. Poor people are exploited and harmed while capitalists or owners are getting profits at the expense of low-income people. Therefore, the issue of income disparity can only be mitigated if not reduced through sincere adhere to the ethical values and principles of Islam. The distribution approaches of Islam are very practical and logical to address various socio-economic upheavals. Besides of redistribution approaches, the concept of halal earnings in Islam has a convincing impact on smooth and just income distribution of income and wealth in the society. This paper can be summarized in the diagram below: 


\section{Figure 1. Conceptual Framework Diagram}

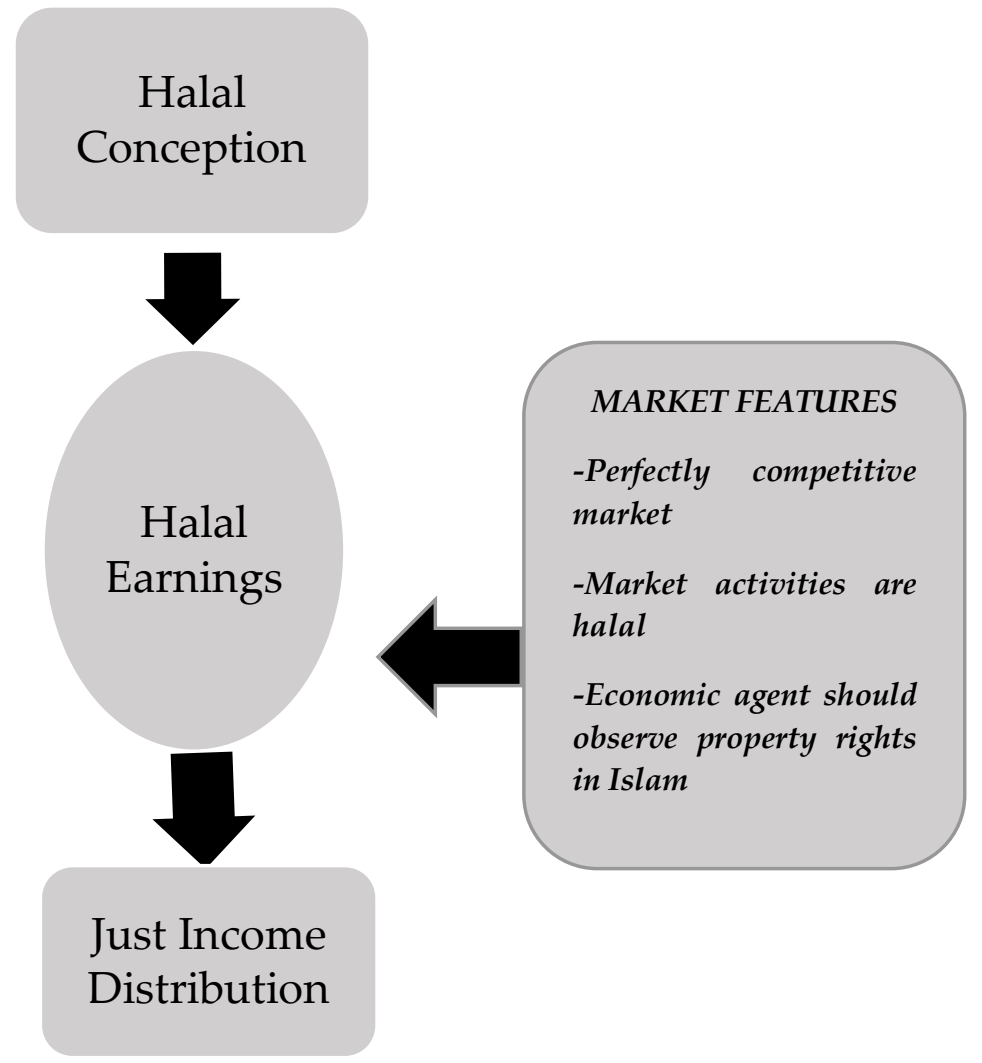

Just income distribution can be achieved through the conception of halal that leads to halal earnings from perfectly competitive and halal markets. Halal markets here are described are those markets that adhere to the principles of halal activities, and products and services prescribed by Shari'ah. Moreover, perfectly competitive market is defined by Gregory Mankiw (2000) as a "market with many buyers and sellers trading identical products so that each buyer and seller is a price taker "(p. 292). From this definition, we can derive some important conditions and characteristics of this market. First, there are large numbers of buyers and sellers in the market. Second, sellers offer standardized or largely the same products. Third, sellers can easily enter into or exit from the market. Fourth, sellers have no control of the market and they are price takers. Fifth, buyers and sellers are well- informed about the products and prices. Competitive market is vital in economy because it tends to economically efficient. In perfectly competitive market, efficient quantity is automatically realized because producers and consumers are left alone to trade with each other and as they want and try to do the best for themselves and as long as the market is working well. So every opportunity in the market is exploited to make someone better off without harming anyone. Conversely, when the market is not perfectly competitive market the economy is inefficient due to market failures (Halls \& Lieberman, 2010, p. 449).Considering the important role of market competition and market forces to achieve economic efficiency, markets must operate within the boundaries of clean mechanism of moral values and the principle of accountability 
before God, justice and human brotherhood (Chapra, 1992, p. 220-221). Generally, Islamic Economic system is a market-based system but the concept of market freedom is just an instrument for efficient resources allocation not the end itself. (Askari, Iqbal\& Mirakhor, 2015, p. 116). The Philosophy of Islamic market competition is different from that of conventional economics. Islamic competition is constrained with Islamic rules and ethical values derived from Shari'ah (Abdelrahman, 2013, 97). Some components of Islamic ethics like effort, competition, transparency, and morally responsible manners and actions are vital to strengthen free and just market activities. The said components if they are practiced, will secure and protect the interests of all economic agents and the flow of the markets because moral values remains the most important protection against malpractices and corruption in the market place (Ali, 2014, p. 46). Hence, the concept of perfectly competitive market in this study is beyond the conventional concept of perfectly competitive market. Certainly, competitive market is not enough to allocate resources efficiently unless it allows halal activities and commodities. Because the concept of haram in Islam is not confined to foods but it comprises of all prohibited things in Islam. Harmfulness and impurities are behind the reason of the prohibition of something. Allah is merciful to his servants and knows best what is proper and improper. When Allah prohibits something and permits something, there is a reason behind it which sometimes explicit and implicit for human intellect. One of the beauties of Islam is that those unlawful things are usually unsafe and Islam provides wide range of alternatives which quite better safer and easier as replacement for those haram things (AlQaradawi, 2013). Anent to this, market which is not halal cannot fully serve the welfare of the consumers and will not sustainably efficient.

Furthermore, for the halal earnings to have an impact on income distribution, economic agent ,consumers and firms, should observe ownership or property right in Islam where everything is solely owned by the Almighty God and the resources held by individuals are only trust. Hence, economic agents must bear in mind that their wealth is subject for zakat when it reaches zakatable amount. If these economic agents adhere to property rights where the poor has the rights to the wealth of the individuals through zakat, then income disparity in the society will gradually reduce.

\section{Conclusion}

The concept of Halal earnings in Islam plays a vital role in the life of Muslims. Its favorable impact on the economy and society is undeniably practical and rational. Halal is not only limited to food consumption but also encompasses all aspects of the life of Muslims. Any type of earnings from unlawful sources is impermissible and Muslims are obliged to avoid it. Islam laid down some few economic activities and practices, which are deemed haram. Consequently, all earnings coming from those prohibited activities are unlawful. Besides, Islam encourages everybody to look for income from various economic activities prescribed by Allah as permissible. Any transaction that causes exploitation and injustices is not acceptable and unlawful. One of the reasons for the huge disparity between rich people and low-income people is the presence of unlawful lucrative professions and economic activities 
that earn a huge amount of profits at the expense of others. These cause the concentration of income and wealth at the hands of few rich people and promote social catastrophe in the form of income inequality. Islam provides approaches and solutions to address the issue of income distribution among people through distribution of factors of production in perfectly competitive market with certain limitations and constraints. Furthermore, Islam provides mandatory and voluntary approaches to reduce income inequality through zakat, sadaqah, inheritance law, waqf, hibah, wasiyah, qardulhanasah, fai, and ghanimah distribution. All of these are strategies to maintain smooth and just distribution of income in society. Besides, Islam also sets preventive approach to the issue of income distribution through the concept and application of halal. Interestingly, the conception of halal in Islam does not only lead to the achievement of best allocation of economic resources and efficiency but it plays vital role to stabilize and maintain the fair and equitable income distribution in the society. Islam condemns and prohibits any type of income earned from any unlawful professions, businesses, and economic activities like gambling, interest, wine, pork, corruption, bribery, cheating, monopolistic practices, and other unacceptable things in Islam. It is quite interesting that if the conceptions of halal earnings will be sincerely practiced, allocation of resources in the market will be achieved and the issue of income inequality will be addressed. The fact that some rich people become richer is due to unlawful professions and economic activities. There are various corporations and ventures dealing with illegal services and products that can harm society and drive the continuous raising of income inequality and poverty. The only good solution for the problem of income distribution is through adherence to the principle of Shari'ah approaches and the motivation to observe the concept of halal earnings. 


\section{References}

Abdelrahman, AY (2013).Fundamental Issues in Islamic Economics. Germany: Verlag Ahmad, M. (2009). Business Ethics in Islam. New Delhi: KitabBhavan

Al Zuhaili, W. (2005) Islam and international law. International Review of the Red Cross.

Ali, Abbas (2014). Business ethics in Islam. UK: Edward Elgar Publishing

Al-Jallad, N. (2008) The concepts of al-halal and al-haram in the Arab-Muslim culture: A translational and lexicographical study, University of Jordan, Language Design 10 (77-86)

Al-Qaradawi, Y. (2001). The Lawful and the prohibited in Islam, Cairo: La-falah Foundation, for Translation, publication and distribution

Al-Qaradawi, Y. (1997 Wealth and Economy in Islam, Cairo: Islamic INC Publishing

Askari, H., Iqbal, Z., \&Mirakhor, A. (2015). Introduction to Islamic economics: Theory and

Application, Singapore: John Willey

Ayub, M. (2007). Understanding Islamic finance. England: John Wiley \& Sons

Case, K., Fair, R. \&Oster, S. (2012). (10th Ed.). Principles of Economics. England: Pearson Education

Chapra, MU (1992). Islam and the Economic challenge. UK: The Islamic Foundation Hall

Darussalam. (2014) Rizqand lawful earnings. Jeddah: Darussalam Publishers

Daudey, E. \&Penalosa, C. (2005).The Personal and the Factor Distributions of Income in a

Dictionary of Economics (2003). London: A \& C Black Publishers

El-Ashker, A., \& Wilson, R. (2006). Islamic economics: A short history. Leiden: Brill.

Frank, R. \& Bernanke, B. (2001) (4 ${ }^{\text {th }}$ Ed.). Principles of Microeconomics. NY: McGraw-Hill/Irwin

Gupta, S. (1998). Does Corruption Affect Income Inequality and Poverty?. IMF Working Papers, 98(76), 1 .

Hall, R. \& Lieberman, M. (2010) (5 ${ }^{\text {th }}$ Edition). Microeconomics: Principles $\mathcal{E}$ application. Mason, USA: South-Western, Cengage Learning

Iqbal, Z. \&Mirakhor, A. (2011) (2 ${ }^{\text {nd }}$ Ed) Introduction to Islamic Finance: Theory and Practice. Singapore: John Wiley

Kaasa, A. (2003). Factors Influencing Income Inequality in Transition Economies. Estonia: Tartu University Press

Kahf, M. (2014). Notes on Islamic Economics: Theories and Institutions. Westminster, USA.

Kamali, MH. (2013) The Parameters of halal and and haram in Sharih and the Halal Industry. USA: The international institute of Islamic thought 
Karim, A. (2005). Islamic banking: Figh and financial analysis. Jakarta: PT Raja GrafindoPersada

Krugman, W. \& wells, R (2005). Microeconomics. New York: Worth Publisher

Luetge, C. (Ed.), (2013). Handbook of the Philosophical Foundations of Business Ethics. London: Springer

Mankiw, G. (2000). (2 $2^{\text {nd }}$ Ed.). Principles of Microeconomics. USA: Harcourt College

Norris, E., Kochhar, K., Suphapiphat, N., Ricka, F. \&Tsounta, E. (2015). Causes and consequences of Income Inequality: global Perspective. International Monetary Fund

Oxfam's International (2017). An economy for the 99\%. Oxfam Briefing Paper file://C:/Users/shldimakuta/Downloads/inequality/oxfam\%20report\%202017.pdf

Sayer, R (2016). Why we can't afford the rich. Bristol: Policy Press

Shafi, Muhammad (1976). (6 th $^{\text {th }}$.) Distribution of Wealth in Islam. Karachi: Begum Aisha Bawany Wakf

Todaro, S. \& Smith, S. (2015) (12 ${ }^{\text {th }}$ Ed.). Economic Development. UK: Pearson Education

Usmani, MI., \& Qazi, B. (2010) Guide to Zakah: Understanding \& Calculation. Pakistan: Maktaba Ma'ariful Qur'an 